Characterization of functionalized bentonite as nanocarrier of salicylic acid with protective action against Pseudomonas syringae in tomato plants

Andrea Y. Mansilla, María F. Salcedo, Silvana L. Colman, Merari T. Chevalier, Matias R. Lanfranconi, Vera A. Alvarez, et al.

\title{
European Journal of Plant Pathology
}

Published in cooperation with the

European Foundation for Plant

Pathology

ISSN 0929-1873

Eur J Plant Pathol

DOI 10.1007/s10658-020-02067-w 
Your article is protected by copyright and all rights are held exclusively by Koninklijke Nederlandse Planteziektenkundige Vereniging. This e-offprint is for personal use only and shall not be self-archived in electronic repositories. If you wish to self-archive your article, please use the accepted manuscript version for posting on your own website. You may further deposit the accepted manuscript version in any repository, provided it is only made publicly available 12 months after official publication or later and provided acknowledgement is given to the original source of publication and a link is inserted to the published article on Springer's website. The link must be accompanied by the following text: "The final publication is available at link.springer.com". 


\title{
Characterization of functionalized bentonite as nanocarrier of salicylic acid with protective action against Pseudomonas syringae in tomato plants
}

\author{
Andrea Y. Mansilla (D) María F. Salcedo • Silvana L. \\ Colman • Merari T. Chevalier • Matias R. \\ Lanfranconi - Vera A. Alvarez • Claudia A. \\ Casalongué \\ Accepted: 28 June 2020 \\ (C) Koninklijke Nederlandse Planteziektenkundige Vereniging 2020
}

\begin{abstract}
Salicylic acid (SA) is a phytohormone with a central role in plant protection against various types of stresses. Exogenous application of SA in plants often requires a fine adjustment of the $\mathrm{pH}$ in the applied solution as well as frequent foliar sprays with a rigorous handling of doses. This work investigates the preparation and characterization of nanocomposites composed of bentonite clays (Bent) and SA as bio-active to produce an efficient and stable hormonal formulation to be used in agriculture. Bent-SA was obtained via cationic exchange reactions of natural Bent with an aqueous solution of SA. The physicochemical properties of Bent-SA were studied in terms of Fourier Transform Infrared Spectroscopy (FTIR), X-Ray Diffraction (XRD) and Thermogravimetric Analysis (TGA). SA was intercalated in a $3.65 \% \mathrm{w} / \mathrm{w}$ interacting by
\end{abstract}

Electronic supplementary material The online version of this article (https://doi.org/10.1007/s10658-020-02067-w) contains supplementary material, which is available to authorized users.

A. Y. Mansilla $(\bowtie) \cdot$ M. F. Salcedo · S. L. Colman • C. A. Casalongué

Instituto de Investigaciones Biológicas (IIB-UE), Consejo

Nacional de Investigaciones Científicas y Técnicas (CONICET), Facultad de Ciencias Exactas y Naturales, Universidad Nacional de Mar del Plata, Dean Funes 3250, 7600 Mar del Plata, Argentina e-mail: amansill@mdp.edu.ar

M. T. Chevalier · M. R. Lanfranconi · V. A. Alvarez Instituto de Investigaciones en Ciencia y Tecnología de Materiales (INTEMA-UE), Consejo Nacional de Investigaciones Científicas y Técnicas (CONICET), Facultad de Ingeniería, Universidad Nacional de Mar del Plata, Avenida Colón 10850, 7600 Mar del Plata, Argentina electrostatic forces between Bent layers. The SA protective activity was investigated in Pseudomonas syringae pv. tomato DC3000 (Pto)-infected tomato plants (Solanum lycopersicum). The expression levels of pathogenesis-related proteins (PRs) were measured by real time quantitative RT-PCR. The genes PR1 and PR5 were up-regulated 2.2- and 1.23-fold, respectively, in 24 h-treated Bent-SA plants. Furthermore, PR3 protein level increased locally and systemically by Bent-SA treatment in plant tissues. The plant disease incidence was significantly reduced in Bent-SA pretreated seedlings. Analyses of DR5:GUS transgenic reporter tomato lines showed that Bent-SA effectiveness was preserved after vehiculization. It was concluded that Bent-SA can provide an environmentally friendly strategy to control tomato plants against $P$ to bacterial infection.

Keywords Bentonite Pseudomonas syringae pv. tomato DC3000 · Salicylic acid · Solanum lycopersicum

\section{Introduction}

Tomato (Solanum lycopersicum L.) is one of the most important horticultural vegetable crops worldwide. There are a number of diseases that affect tomatoes including bacterial speck which is caused by the bacterial pathogen Pto. Its symptoms appear in a form of black necrotic specks surrounded by a yellow halo on leaves, stems, and fruits (Jones et al. 2016). Bacterial speck can cause up to $75 \%$ losses in yield and is recognized as a significant source of economic loss in the 
tomato industry (Jones et al. 2016). Control of Ptomediated disease can be achieved through limited options of chemical control. The antibiotic streptomycin has been used to control bacterial speck but resistance is common in pathogen populations and thus, its use is strongly regulated (McManus et al. 2002). With respect to chemical control, copper-based products are often used worldwide. However, the rapid development of plasmid mediated copper-tolerance has rendered these compounds relatively ineffective (Shenge et al. 2008). Combining these compounds with the ethylene bisdithiocarbamate (EBDC) fungicides such as mancozeb has provided improved levels of control even in copper tolerant microbial populations (Conlin 2008). However, these combinations are only moderately effective and cause a lot of damage to humans and the environment. Search for alternatives, including more environmentally sustainable options, is an important topic in phytopathology. In this sense, natural compounds acting as priming of plant innate immunity represent an excellent alternative for modern agriculture (González-Bosch 2018). The anti-stress phytohormone SA is a lipophilic phenolic acid hormone with roles in several growth and developmental processes, including the activation of plant defense responses against several pathogens (Zhang and Li 2019). Systemic Acquired Resistance (SAR) has been recognized as a plant response to biotic stress for almost 100 years (Ryals et al. 1996). Much more recently, direct evidence for the role of SA in SAR comes from the identification and characterization of Arabidopsis thaliana isochorismate synthase (sid2-2) mutant with reducing level of SA (Wildermuth et al. 2001). Likely, once the SA is synthesized, it acts through receptors belonging to the NPR (non-expressor of pathogenesis-related proteins) family of transcription factors to further induce defense-related genes contributing to the activation of pathogenassociated molecular pattern (PAMP)-triggered immunity (PTI), effector-triggered immunity (ETI), and SAR (Zhang and Li 2019). Nowadays, SA is accepted as an essential hormone for both local resistance and SAR (Durrant and Dong 2004). The application of SA on plants induces endogenous SA accumulation conferring plant resistance against different pathogens (Vallad and Goodman 2004). However, SA has controversial roles in development and plant growth depending on its concentration, the $\mathrm{pH}$ of the application solutions as well as plant species and developmental stages (Rivas-San Vicente and Plasencia 2011). Per example, depending of plant species, high dose of SA (>1-2 mM SA) not only enhances plant resistance, but also it negatively regulates plant development processes impacting on crop productivity (Koo et al. 2020). SA has been reported to inhibit seed germination and block the wound response (Davies 2010). Another matter to consider for the exogenous SA application is that in general, the $\mathrm{pH}$ of SA solution is acidic. However, SA uptake by plant cells is $\mathrm{pH}$ dependent. In tobacco cells, SA uptake is inversely correlated with the increase of medium $\mathrm{pH}$ (Chen and Kuc 1999). Thus, both fine adjustment of $\mathrm{pH}$ as well as application doses of SA could be critical in the modulation of SA-mediated plant defense signaling (Karlidag et al. 2009; Dempsey and Klessig 2017; Youssef et al. 2017).

Bentonites are multifunctional clay minerals that possess unique properties; importantly, swelling and adsorption characteristics (Park et al. 2016). Bentonites have been applied to develop diverse drug delivery systems to overcome the pharmaceutical disadvantages of many drugs, that include low solubility and poor low bioavailability and short biological half-life; i.e. pharmacokinetic properties (McNerny et al. 2010; Savjani et al. 2012; Mould et al. 2015). In agriculture, several studies have suggested its use in the development of agrochemicals such as fertilizers, plant growth promoters and pesticides (Olanrewaju et al. 2000; Bin Hussein et al. 2009). However, most reports have only concerned system characterization and do not provide information on the biological efficacy of these systems (El-Nahhal et al. 1999; Lakraimi et al. 2000). In general, Bentonite clays (Bent) are able to accommodate a variety of active molecules on their inter-lamellar spaces (Czaban and Siebielec 2013). The thickness of the clay sheets is in the order of a nanometer and its length can reach several microns (Majeed et al. 2013). A previous study demonstrated the adsorption of SA on Bent for its controlled release and putative application in pharmacological field (Bonina et al. 2007). Based on the low solubility of SA in water (Shalmashi and Eliassi 2008), and in addition to the fact that SA is easy and quickly metabolized we hypothesized that SA vehiculization in Bent could be an interesting strategy to facilitate its delivery in aqueous solutions providing also, bioavailability, efficiency and chemical stability on the target plant tissue/organ. The main purpose of our study is to obtain and characterize Bent-SA as carrier matrix to be applied against protection to Pto -mediated disease in tomato plants. 


\section{Materials and methods}

Materials

Bent was provided by Minarmco, Argentina and SA was provided by Sigma-Aldrich (USA). The chemical composition of used clay was previously reported by our group as following: $\mathrm{SiO}_{2}: 52.3 \%, \mathrm{Al}_{2} \mathrm{O}_{3}: 13.1 \%$, $\mathrm{Fe}_{2} \mathrm{O}_{3}: 22.1 \%$; $\mathrm{MgO}: 1.9 \%, \mathrm{CaO}: 4.7 \%, \mathrm{~K}_{2} \mathrm{O}: 1.3 \%$, $\mathrm{TiO}_{2}$ : 2\%; P: 0\%; others: 2.4\% (D'Amico et al. 2014).

\section{Bent-SA preparation}

The Bent-SA nano-clay was prepared according to our patented procedure (Patent WO 2017/060869 Al). Briefly, Bent-SA was obtained by cationic exchange by preparing a solution of the active agent and stirred it with a Bent dispersion in distilled water for $2 \mathrm{~h}$. The nanoclays were then centrifuged, washed 3 times with distilled water, and lyophilized. For application in plants, dried powder of Bent-SA suspensions was re-suspended in water with a final adjusted $\mathrm{pH}$ 6.5-7. For SA free controls, a $1 \mathrm{mg} \mathrm{mL}^{-1}$ stock solution adjusted to $\mathrm{pH} 6.5$ with $1 \mathrm{~mol} \mathrm{~L}^{-1}$ $\mathrm{NaOH}$ was prepared.

Physico-chemical characterization of Bent and Bent-SA

$T G A$

Analyses were performed using TA Auto-MTGA Q500 Hi-Res equipment, from $30{ }^{\circ} \mathrm{C}$ to $900{ }^{\circ} \mathrm{C}\left(15^{\circ} \mathrm{C} / \mathrm{min}\right)$ in air atmosphere.

$X R D$

The X-Ray patterns were obtained in an Analytical Expert Instrument equipment $(\mathrm{K} \infty \mathrm{Cu}=1.54 \AA)$ from $2 \theta=3^{\circ}$ to $60^{\circ}(2 \%$ minute $)$ at ambient temperature. The generator voltage was $40 \mathrm{kV}$ and the current was $40 \mathrm{~mA}$.

By using the Bragg's Law:

$n \lambda=\mathbf{2} \operatorname{sen} \theta . d$

Where: $n$ is an integer, $\lambda$ is the $\mathrm{X}$-Ray wavenumber, $\theta$ is the diffraction angle, it is possible to determine the distance between the planes of the crystal lattice, $d$.
FTIR spectra, measured by attenuated total reflectance (ATR), were acquired with a Nicolet 6700 Thermo Scientific instrument, over the range $400-4000 \mathrm{~cm}^{-1}$ from 32 co-added scans at $4 \mathrm{~cm}^{-1}$ resolution.

Transmission Electron Micrographs (TEM) were taken in a JEOL JSM-6460 LV instrument. The sample was well-dispersed in butanol. Then, a drop of it was placed on a holey carbon copper grid for TEM image obtaining. Micrographs were obtained at $150000 \times$ magnification, and the "Image Pro Plus" software was used to perform the measurements.

In vitro SA release from Bent-SA

In vitro SA release from Bent-SA was investigated in water suspensions for a total period of $72 \mathrm{~h}$. Briefly Bent-SA $(5 \mathrm{mg})$ were dispersed in distilled water $(1 \mathrm{~mL})$ at $25^{\circ} \mathrm{C}$, after fixed time frame total suspensions were filtered and frozen for further quantification. SA was measured by high performance liquid chromatography (HPLC) system (Shimadzu, Prominence, Japan) equipped with a diode array detector (DAD).

Biological characterization

\section{Biological material}

Solanum lycopersicum var. Platense seeds were obtained from FECOAGRO Ltda. (San Juan, Argentina). Tomato var. Micro-Tom seeds from the transgenic line DR5:GUS were kindly donated by Dr. Agustin Zsögön (Universidade Federal de Viçosa, Brazil). DR5:GUS plants express the reporter gene beta-glucuronidase (GUS) under a synthetic auxin-responsive promoter (Silva et al. 2018). SA-mediated activity on auxinmediated response was also tested in tomato reporter plants.

Pto (NCPPB, USA, collection number 1008), a well characterized Gram-negative bacterium was used (Cecchini et al. 2011). Pto was maintained on King's B (KB) agar medium (King et al. 1954) containing $50 \mathrm{mg} \mathrm{L}^{-1}$ rifampicin and $50 \mathrm{mg} \mathrm{L}^{-1}$ kanamycin as suitable antibiotics.

\section{Tomato growth conditions}

Tomato Platense and Micro Tom seeds were surfacesterilized in $30 \%(\mathrm{v} / \mathrm{v})$ hypochlorite and $0.2 \%(\mathrm{v} / \mathrm{v})$ 
Tween-20 for $10 \mathrm{~min}$, followed by three washing steps in sterilized distilled water. Sterilized seeds were placed on Murashige and Skoog (MS) medium (Murashige and Skoog 1962) plus $0.8 \%(w / v)$ agar in Petri plates and grown at $25{ }^{\circ} \mathrm{C}$ under $120 \mu \mathrm{mol}$ photons $\mathrm{m}^{-2} \mathrm{~s}^{-1}$ with 16:8 h light:dark cycles until treatments.

To study SA- mediated SAR and local defense responses on tomato, 40-day-old plants were used. In this assay, seeds were sowed in 15-cm diameter plastic pots containing Grow Mix Multipro (Terrafertil, Argentina) as substrate and incubating during 5 days at $25^{\circ} \mathrm{C}$ in the dark. After germination, plants were cultivated at $25^{\circ} \mathrm{C}$ under $120 \mu \mathrm{mol}$ photons $\mathrm{m}^{-2} \mathrm{~s}^{-1}$ with $16: 8 \mathrm{~h}$ light:dark cycles.

\section{Bent-SA and Bent treatments}

To evaluate the SA-mediated activities of Bent-SA on tomato, 10-day-old plantlets were sprayed with $2 \mathrm{mg} \mathrm{mL} \mathrm{m}^{-1}$ of Bent-SA and $2 \mathrm{mg} \mathrm{mL}^{-1}$ Bent or free $70 \mathrm{mg} \mathrm{L}^{-1} \mathrm{SA}$ as the maximum estimated concentration available from the nanoclay composite. The assayed concentration of free SA is usually applied to induce plant defense response (Chandrasekhar et al. 2017). After $24 \mathrm{~h}$, fresh tissue $(100 \mathrm{mg})$ were collected and analyzed by western blots and real-time PCR analysis.

To analyze SA-mediated effects, the second leaf from 40-day-old tomato plants was sprayed with $2 \mathrm{mg} \mathrm{mL}^{-1}$ of Bent-SA or $2 \mathrm{mg} \mathrm{mL}^{-1}$ Bent. After $24 \mathrm{~h}$, the second and third leaves were collected to analyze SA-mediated local and systemic responses, respectively. Collected samples were stored at $-80^{\circ} \mathrm{C}$ until subsequent processing for immunoblotting analysis.

\section{Tomato infection assays}

Tomato seedlings were infected according to Uppalapati et al. (2008). Briefly, an overnight culture of the Pto was diluted with a sterile solution of $10 \mathrm{mmol} \mathrm{L}^{-1} \mathrm{MgCl}_{2}$ and $0.025 \%(v / v)$ SILWET L-77 (OSI Specialities Inc., Danbury, CT, USA) as surfactant until reaching an $\mathrm{OD}_{600}=0.1$. To achieve uniform inoculation, the cell suspension was dispensed into Petri dishes until seedlings were submerged. Then, seedlings were exposed to bacterial cells with gentle mixing for $5 \mathrm{~min}$. After the inoculum was discarded, Petri dishes containing inoculated seedlings were sealed with parafilm and incubated at $18{ }^{\circ} \mathrm{C}$ with light intensity of $120 \mu \mathrm{mol}$ photons $\mathrm{m}^{-2} \mathrm{~s}^{-1}$ with $16: 8 \mathrm{~h}$ light/dark cycles. The symptoms in cotyledons were observed after 4 days of inoculation. As mock control, seedlings were flooded in $10 \mathrm{mmol} \mathrm{L}^{-1} \mathrm{MgCl}_{2}$ and $0.025 \%$ (v/v) SILWET L-77. The damage or lesion area in tomato cotyledons was measured using the image-processing software Image J (NIH, Maryland, USA) and related to $100 \%$ as the total cotyledons area. Nearly, 15 seedlings were examined in each experiment. Independent experiments were repeated at least three times.

\section{Quantification of Pto remained in tomato cotyledons}

Bacterial growth in tomato seedlings was measured by determining the remaining bacteria in the leaf tissue at the end of the experiment according to Mansilla et al. (2013). To remove epiphytic bacteria, seedlings were surface-sterilized with $70 \%(\mathrm{v} / \mathrm{v})$ ethanol for $1 \mathrm{~min}$. Nearly $100 \mathrm{mg}$ of green tissue from seedlings were washed twice with sterile distilled water and then homogenized in cold and sterile distilled water $(1 \mathrm{~mL})$ using a pestle in sterile microcentrifuge tubes. The homogenates were vortexed for $5 \mathrm{~s}, 10$-fold serially diluted and cultured on $\mathrm{KB}$ medium plates supplemented with $50 \mathrm{mg} \mathrm{L}^{-1}$ kanamycin and $50 \mathrm{mg} \mathrm{L}^{-1}$ rifampicin. Plates were placed at $30^{\circ} \mathrm{C}$ for 2 days. For each dilution, the number of Pto colony-forming units (CFU) was counted.

\section{Protein extraction and immunoblotting assays}

Total soluble proteins were extracted from leaf fresh tissue $(60 \mathrm{mg}$ ) in protein extraction buffer (AS08 300, Agrisera, Sweden) supplemented with the protease inhibitor cocktail ( ${ }^{\circ}$ P9599 Sigma-Aldrich, USA). After centrifugation at $12,000 \times \mathrm{g}$ for $15 \mathrm{~min}$, the supernatant was collected and boiled for $5 \mathrm{~min}$ in SDS-PAGE Laemmli's sample buffer. Samples were run on $12 \%$ $(w / v)$ SDS-PAGE, electrotransfered onto nitrocellulose membranes and probed with 1:5000 of anti PR3 primary antibodies (AS07 207, Agrisera, Sweden) overnight followed by incubation with 1:7000 anti-rabbit secondary antibody conjugated to alkaline phosphatase (Invitrogen, USA). As a protein defense marker, PR3 pathogenesis-related protein abundance was measured at $24 \mathrm{~h}$ after treatment (Sudisha et al. 2012). Western blot assays were performed in triplicate. Ponceau's staining was used as a loading control in each lane. 
RNA isolation and quantitative real-time $R T-q P C R$ analysis

Total RNA from cotyledons sprayed with $2 \mathrm{mg} \mathrm{mL}^{-1}$ of Bent-SA, Bent or free SA $\left(70 \mathrm{mg} \mathrm{L}^{-1}\right)$, was extracted using TRIzol reagent (Invitrogen, USA) according to the manufacturer's recommendations. Samples were treated with RQ1 RNase-free DNase (Promega, USA) for DNA contamination removal. For cDNA synthesis, total RNA $(1 \mu \mathrm{g})$ was reverse transcribed by IMPROM II (Thermo Fisher Scientific, USA) using random primers (Biodynamics, Argentina). The nucleotide sequences of the specific primers for qPCR analysis of SIPR1a and SIACT were previously reported (Vossen et al. 2010). The primers used for SIPR5 were 5'AAACGGTGAATGCCCTAGTC-3' (forward primer) and5'-ATTGTTGTCCTCCGAACGTG -3' (reverse primer). qPCR reactions were conducted in triplicates $\left(95{ }^{\circ} \mathrm{C}\right.$ for $10 \mathrm{~min}$, followed by 40 cycles of $95^{\circ} \mathrm{C}$ for $30 \mathrm{~s}, 60^{\circ} \mathrm{C}$ for $30 \mathrm{~s}$ and $72{ }^{\circ} \mathrm{C}$ for $30 \mathrm{~s}$ ) in a Step One real-time PCR system (Applied Biosystems, USA) using FastStart Universal SYBR Green Master Rox (Roche, Germany) following manufacturer's instructions. Results were normalized to the expression level of actin gene (SIACT) and expressed as fold-change over the levels of the controls using the comparative cycle threshold (CT) method (Pfaffl 2001). PCR products were analyzed by melting curve analysis to confirm the presence of a single product.

\section{DR5:GUS auxin reporter seedlings}

The repression of auxin signaling by SA has been previously demonstrated by Wang et al. (2007) in Arabidopsis thaliana. In this work, the activity of Bent-SA was analyzed on the repression of DR5:GUS tomato reporter seedlings. To induce the auxin pathway, 5-day-old DR5: GUS seedlings were transferred to liquid MS medium supplemented with $22 \mathrm{mg} \mathrm{L}^{-1}$ synthetic auxin, 2,4-dichlorophenoxyacetic acid (2,4-D). Then $2 \mathrm{mg} \mathrm{mL}^{-1}$ Bent-SA, $2 \mathrm{mg} \mathrm{mL}^{-1}$ Bent or $70 \mathrm{mg} \mathrm{L}^{-1}$ SA was added to the supplemented MS medium. After $24 \mathrm{~h}$, seedlings were removed and fixed in $90 \%(\mathrm{v} / \mathrm{v})$ acetone for $1 \mathrm{~h}$ at $20{ }^{\circ} \mathrm{C}$, washed twice with $50 \mathrm{mmol} \mathrm{L}^{-1}$ sodium phosphate buffer $\mathrm{pH} 7.0$ and incubated in staining buffer $\left[50 \mathrm{mmol} \mathrm{L}^{-1} \mathrm{Na}\right.$ phosphate (pH 7.0), 0.1\% (v/v) Triton X-100, $5 \mathrm{mmol} \mathrm{L}^{-1}$ EDTA, $0.5 \mathrm{mmol} \mathrm{L}^{-1} \mathrm{~K}_{3} \mathrm{Fe}(\mathrm{CN})_{6}, 5 \mathrm{mmol} \mathrm{L}^{-1} \mathrm{~K}_{4} \mathrm{Fe}(\mathrm{CN})_{6}$, containing $1 \mathrm{mg} \mathrm{mL}^{-1} \mathrm{X}$-Gluc (5-bromo-4-chloro-3-
indolyl-beta-D-glucuronic acid, cyclohexylammonium salt (Gold Biotechnology, USA)] as substrate. Mix was incubated at $37{ }^{\circ} \mathrm{C}$ for $2 \mathrm{~h}$ to overnight. Images were taken using a scanner (Epson Perfection V600 Photo, Indonesia).

Statistical analysis

The values shown in figures are mean values \pm standard deviation (SD) of at least three independent experiments. The data were subjected to ANOVA with Tukey post hoc comparisons against control using Graphpad Prism version 5.01 software $(* p<0.05, * * p<0.01$, $* * * p<0.001)$.

\section{Results and discussion}

Physico-chemical characterization of Bent and Bent-SA

The powder XRD patterns of the original and Bent-SA hybrid are shown in Fig. 1.

The XRD tests were carried out in order to see if SA molecules were effectively intercalated between Bent layers which were expected. The parameter commonly used to determine the occurrence of cation exchange reactions is the shifting of the peak position to lower angles due to increase on the interlayer distance, $d_{001}$ (Günister et al. 2007). The distance between the planes of the crystal lattice for original Bent was $11.5 \AA$ (reflection peak at $2 \theta=7.7^{\circ}$ ) whereas for Bent-SA nano-clay this parameter was $15.7 \AA$. TEM images (Online Resource 1) showed interlaminar spacing of the order of $11.8 \AA$ for Bent, which is in agreement with the results observed by XRD. The observed increase on the interlayer space (4.2 $\AA$ ) of the clay after modification with SA in turns indicates that, at least some of the phytohormone was intercalated and is housed in the clay strata. It is possible that SA molecules are oriented in a monolayer arrangement between clay layers forming complexes with ferric ions (Fig. 2).

The thermal stability of Bent, Bent-SA and SA was evaluated by TGA and the obtained curves are shown in Fig. 3. From the previous curves it can be seen that Bent exhibited two main steps of mass loss. The first one, between room temperature and $150{ }^{\circ} \mathrm{C}$, is associated to desorption of water molecules $(10.5 \% \mathrm{w} / \mathrm{w})$ and the other, between 400 and $700{ }^{\circ} \mathrm{C}$, with the loss of structure 
Fig. 1 XRD pattern for Bent and for Bent-SA hybrid

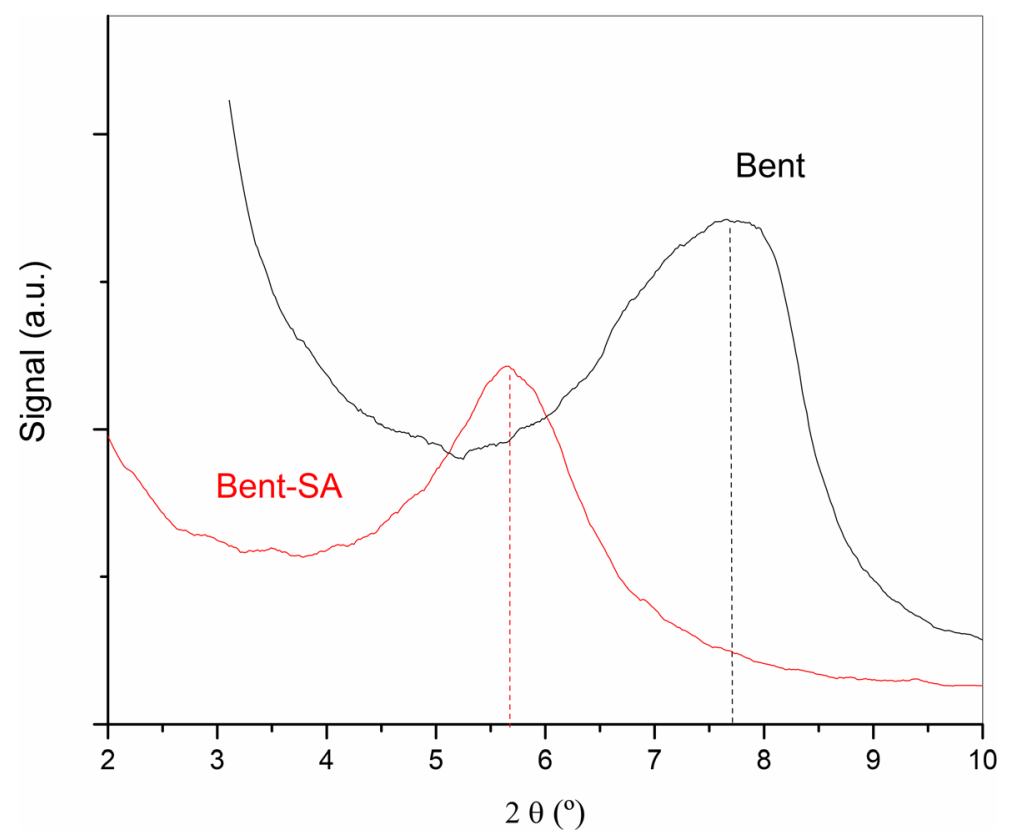

of the hydroxyl group (4.6\% w/w) (Futalan et al. 2011). On the other hand, SA degrades in only one step centered at $192{ }^{\circ} \mathrm{C}$ (Wesołowski 1979). This peak was also present in the case of Bent-SA nanoclays but situated at relatively higher temperatures $\left(201{ }^{\circ} \mathrm{C}\right)$. This peak would indicate retarded degradation of intercalated SA and protective effect of bentonite.

In addition, SA intercalated into Bent was determined by subtracting the residual mass of Bent between $170{ }^{\circ} \mathrm{C}$ and $800{ }^{\circ} \mathrm{C}$ from the residual mass of Bent-SA in the same range of temperatures. Thus, it was found that the SA intercalated in Bent was approximately $3.65 \%$ $(w / \mathrm{w})$, and, as it was observed by XRD, that its molecules are probably oriented in a monolayer arrangement.

Figure 4 shows the infrared spectra of the original and Bent modified clays. The main absorption bands of Bent have appeared at: $986 \mathrm{~cm}^{-1}$, which corresponds with the stretching vibration frequency of the Si-O; $1635 \mathrm{~cm}^{-1}$, which is associated with the bending frequency of water molecules absorbed on clay surface; $3400 \mathrm{~cm}^{-1}$, corresponding to the stretching vibration frequency of $\mathrm{O}-\mathrm{H}$ water molecules adsorbed and a band at $3621 \mathrm{~cm}^{-1}$, related to the stretching vibrations of structural O-H groups (Darder et al. 2003; Nayak and Singh 2007; Monvisade and Siriphannon 2009).

In the case of Bent-SA, the reduction of the peak corresponding to the hydroxyls $(\mathrm{OH})$, centered at $3500 \mathrm{~cm}^{-1}$ and the carbonyl group $(\mathrm{C}=\mathrm{O})$ centered at
$1710 \mathrm{~cm}^{-1}$ could be related to the intercalation of the SA in the clay sheets (Trivedi et al. 2015).

In vitro SA release

In order to ensure the efficacy of Bent as carrier of SA in vitro release studies were performed. As shown Fig. 5 the aqueous suspension of Bent-SA showed an initial fast release phase followed by a constant release. Particularly, the solution sampled after $4 \mathrm{~h}$ already contains almost the maximum amount of SA released $(7.51 \% \mathrm{w} /$ $\mathrm{w}$ of the amount adsorbed by Bent), and then can be considered constant until $72 \mathrm{~h}$ analyzed.

In agreement with Bonina et al. (2007), the amount of SA released by Bent is not very high. At $24 \mathrm{~h}$, these authors reported a maximum release of $1.4 \%(\mathrm{w} / \mathrm{w})$ comparable to the $7.2 \%(\mathrm{w} / \mathrm{w})$ release here demonstrated. This result could be correlated with the strong interaction between SA and Bent by means of ferrum complex. However, unlike reported by these authors, the release of the SA was quick, obtaining a sustained release during the first $4 \mathrm{~h}$ and then reaching a plateau.

Characterization of Bent-SA defense activity in planta

Since SA regulates multiple physiological responses the innate immunity response, the expression of SA 
Fig. 2 Schematic representation of SA oriented in a monolayer between Bent sheets

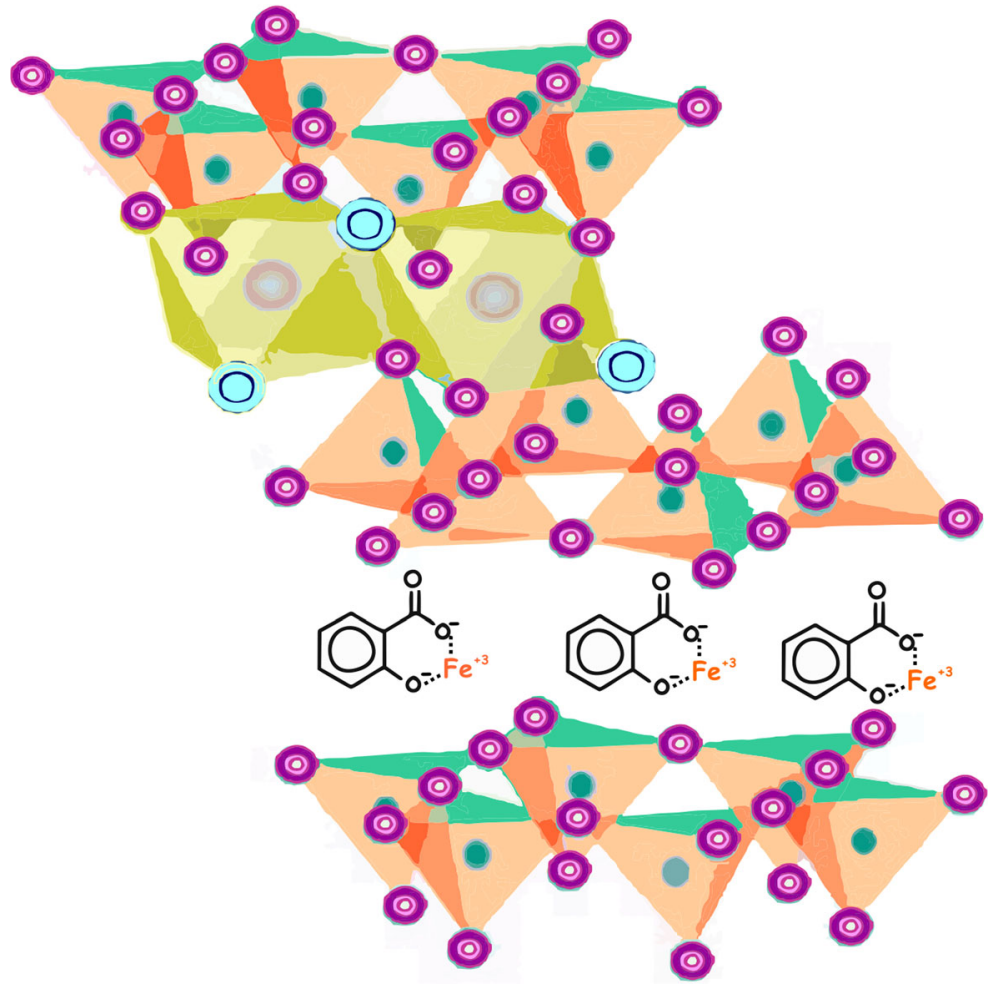

expression of these two genes was remained at levels as low as or close to controls in Bent-treated plants. The activation of $P R 1$ and $P R 5$ gene expression revealed that foliar application of functionalized nanoclay triggered plant defense responses suggesting that SA remained bioavailable and effective for its action in plants.
Fig. 3 TGA curves of the Bent, SA y Bent-SA

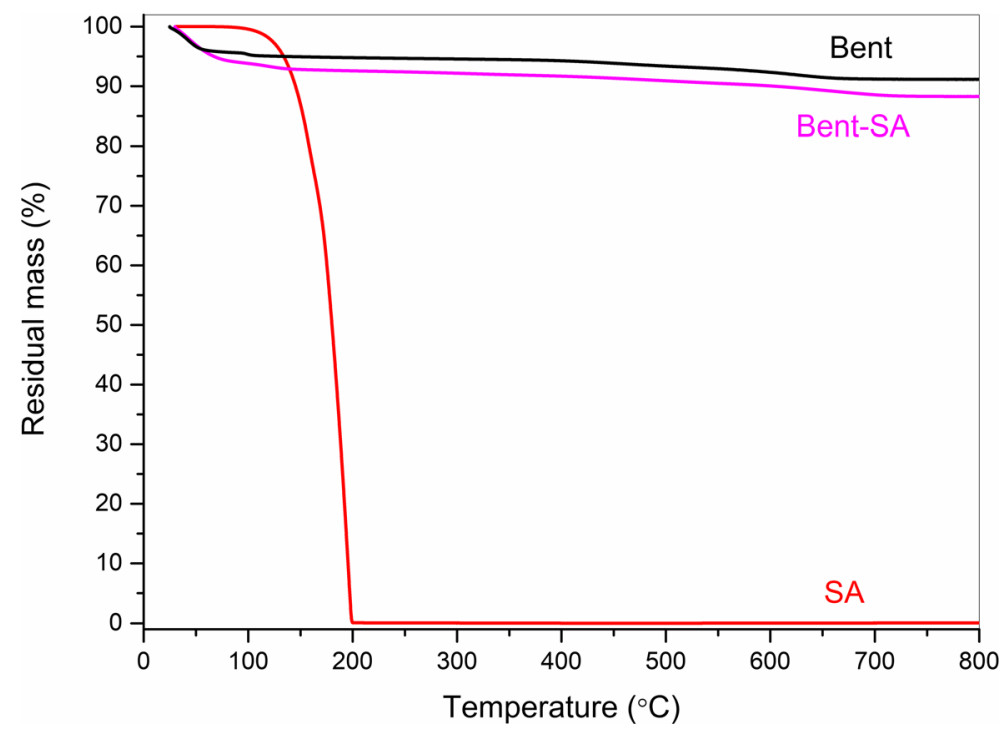


Fig. 4 FTIR spectra of Bent and Bent-SA hybrid

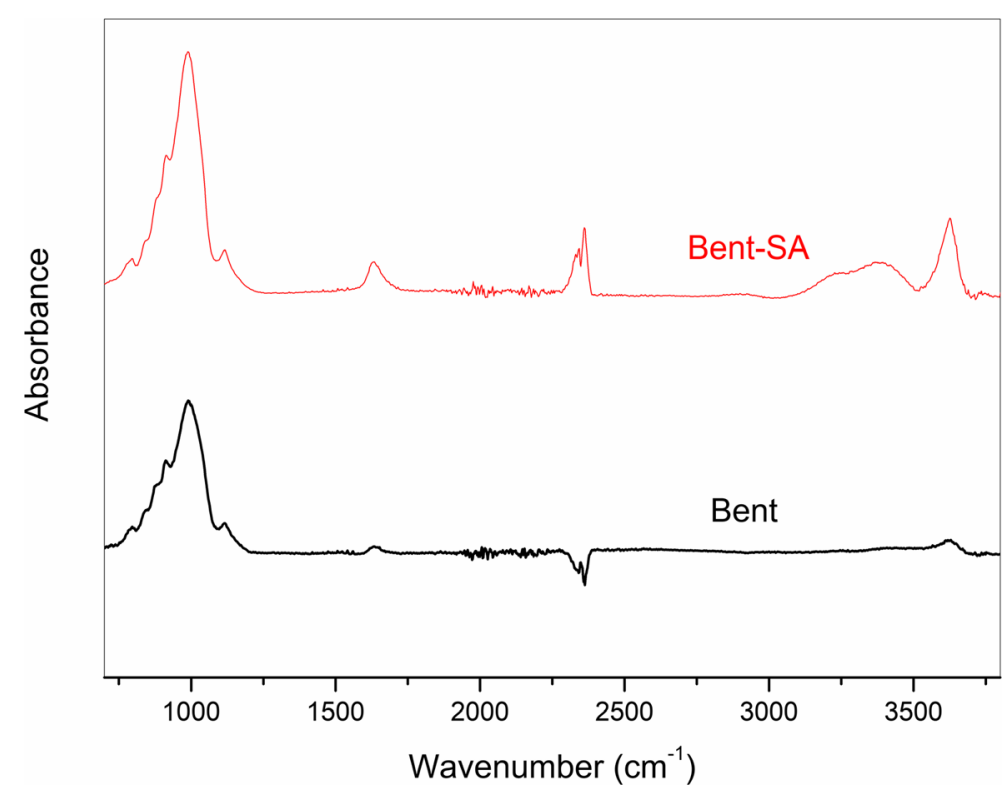

Protection of tomato plants against Pto infection by Bent-SA

To investigate the action of Bent-SA on the protection against $P$ to infection, $2 \mathrm{mg} \mathrm{mL}^{-1}$ Bent-SA were applied on tomato seedlings and then infected with Pto. Compared with Bent, the application of Bent-SA significantly decreased bacterial damages in tomato cotyledons (Figs. 7a and b). Then CFU of Pto bacterium was quantified in order to test if Bent-SA-mediated protection was correlated with a reduction in the bacterial remaining inoculum in tomato tissue. Infected tissue was collected from 4 days post-inoculated seedlings, previously treated with Bent-SA or Bent. A strong reduction in the estimated CFU value was correlated in tomato seedlings treated with Bent-SA indicating that SA-mediated activity is guarantee in this composite material. The developed Bent-SA nanostructures clearly represents an system that can be applied to control the bacterial infections in tomato; improving the disadvantages of free SA and being naturally available, easily prepared, cheap and environmentally friendly (Elsharkawy and Mousa 2015).
Fig. 5 In vitro release profile of Bent-SA. Data representing SA cumulative release in percentage. Data are mean values of 3 independent experiments $\pm \mathrm{SD}$

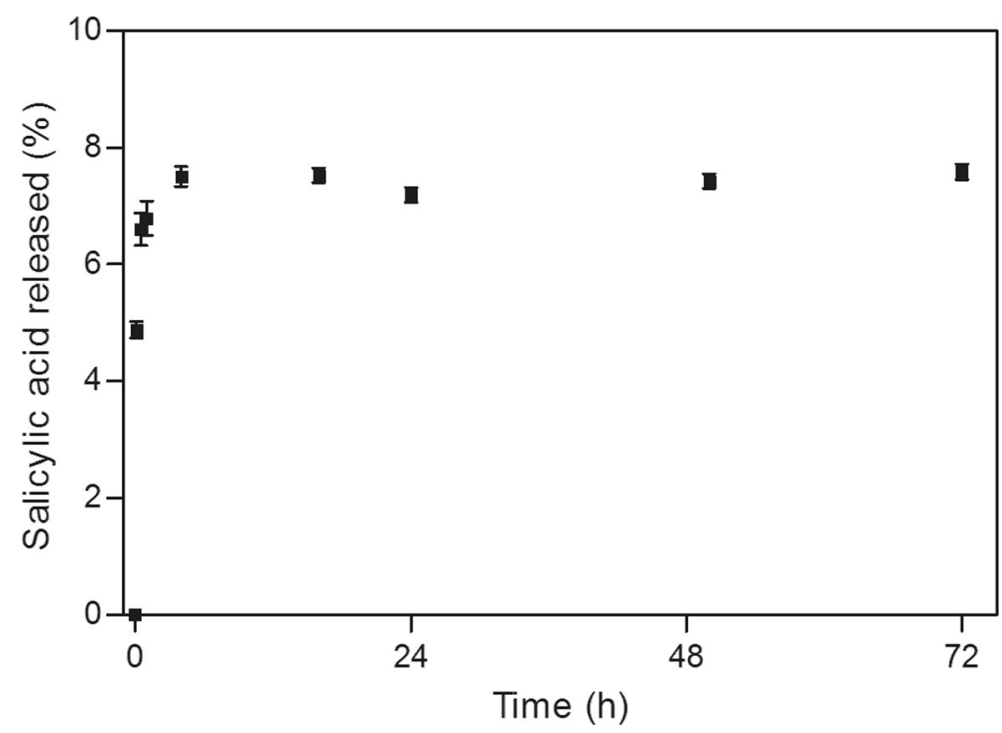




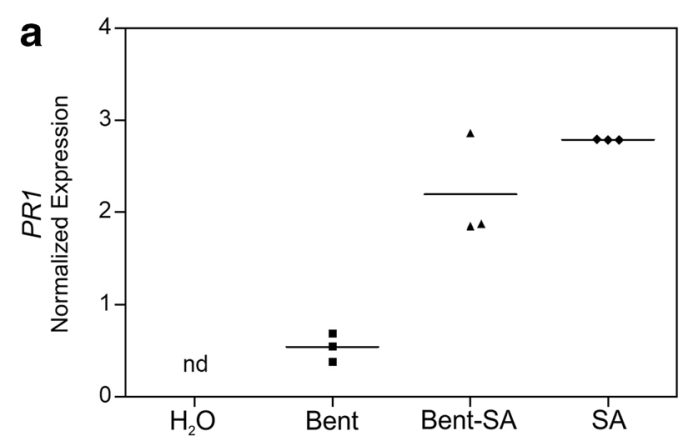

Fig. 6 Bent-SA promotes the activation of $P R s$ genes in tomato. Ten-day-old seedlings were treated with $2 \mathrm{mg} \mathrm{mL}^{-1}$ Bent-SA or $2 \mathrm{mg} \mathrm{mL}^{-1}$ Bent. $\mathrm{H}_{2} \mathrm{O}$ and $70 \mathrm{mg} \mathrm{L}^{-1} \mathrm{SA}$ were used as negative

\section{Analysis of SA-mediated local and SAR responses}

In order to extend this present analysis to more productive field conditions, Bent-SA was applied in 40-day-old plants. By immunoblotting, the abundance of PR3 protein as a defense marker was analyzed in Bent and BentSA-treated plants. In this experiment, SAR and local

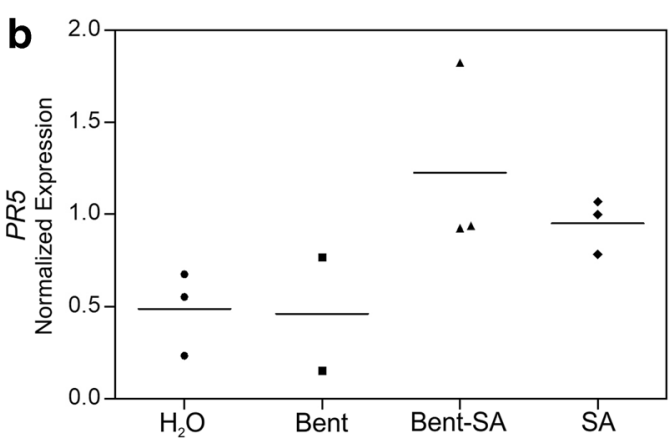

and positive controls, respectively. Transcript expression levels of PR1 (a) and PR5 (b) were analyzed by qPCR after $24 \mathrm{~h}$ of treatments. Data are from 3 independent biological replicates

defense responses were also analyzed. Compared with Bent, in Bent-SA-treated plants the level of PR3 protein increased both local and systemically (Fig. 8). As expected, PR3 protein corresponding to a molecular weight of approximately $34 \mathrm{kDa}$ was detected (Falcioni et al. 2014). Due to Bent-SA-mediated local and systemic defense responses in tomato plants we
Fig. 7 Bent-SA counteracts Pto colonization in tomato seedlings. a, Tomato were pretreated with $2 \mathrm{mg} \mathrm{mL}^{-1}$ Bent-SA or $2 \mathrm{mg} \mathrm{mL}^{-1}$ Bent as control, and then immersed in Pto cell suspension. Photographs were taken at 4 days post-inoculation. b, The total area affected by Pto in Bent or Bent-SA-treated cotyledons was quantified; $100 \%$ represents the total area of cotyledons corresponding to each treatment. c, Quantification of CFU from pretreated-cotyledons and after 4 days post-inoculation. Values were expressed as the logarithm of CFU. Data are means $( \pm \mathrm{SD})$ of three independent experiments. Statistical analysis was performed by one-way ANOVA analysis of variance, ${ }^{*} p<0.05$ (Tukey'stest) a

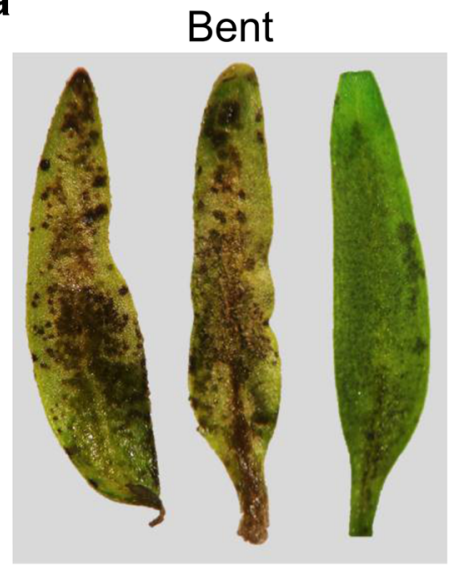

b

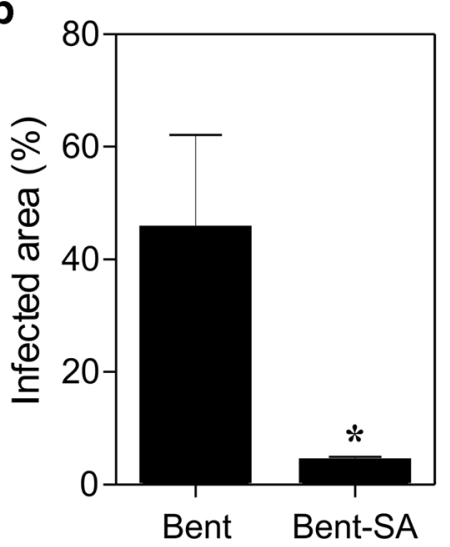

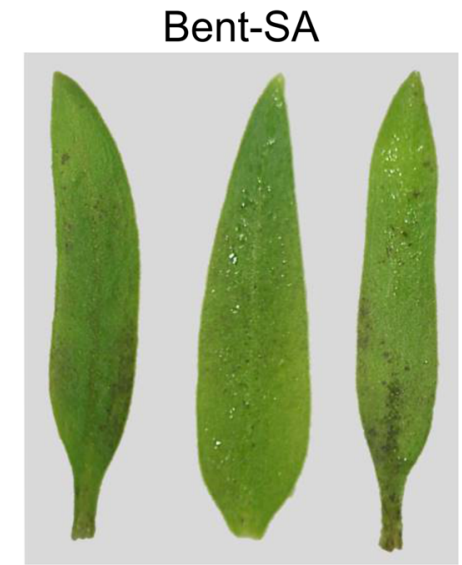

c

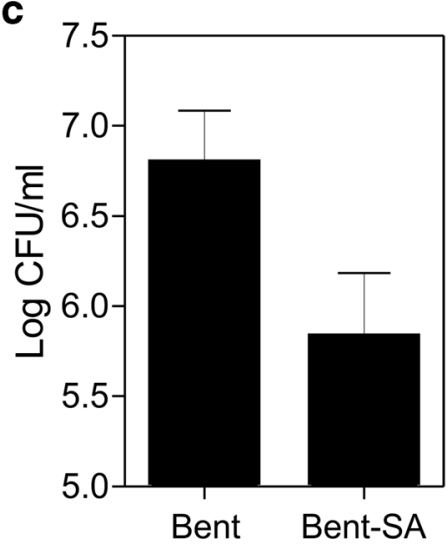




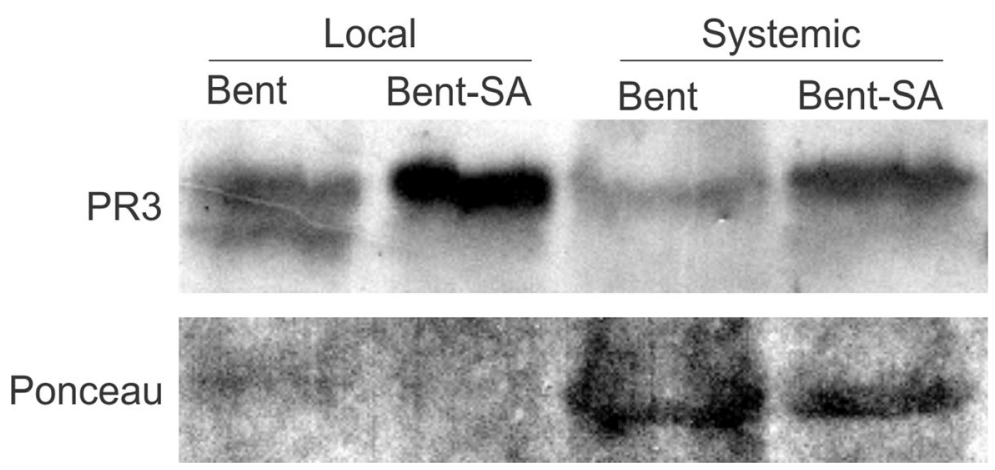

Fig. 8 PR3 protein is both local and systemically accumulated in Bent-SA treated tomato plants. Forty-day-old tomato plants were sprayed with $2 \mathrm{mg} \mathrm{mL}^{-1}$ of Bent or $2 \mathrm{mg} \mathrm{mL}^{-1}$ Bent-SA. At $24 \mathrm{~h}$

speculate that this clay could result in an efficient protection of tomato against Pto bacterial infection in the field.

\section{Assay of SA activity in roots}

Since SA has been shown to inhibit expression of auxinmediated response in Arabidopsis thaliana transgenic lines (Wang et al. 2007) we investigated the action of Bent-SA on roots of DR5:GUS transgenic plants. As with the control, GUS reporter activity was measured in $22 \mathrm{mg} \mathrm{L}^{-1}$ 2,4-D treated roots in which the DR5 promoter is most active. Similar results were apparent in $22 \mathrm{mg} \mathrm{L}^{-1}$ 2,4-D plus Bent-treated roots. However, as expected, the application of $2 \mathrm{mg} \mathrm{mL}^{-1}$ Bent-SA abolished 2,4-D-mediated activation validating the expected biological functionality of this nanocomposite in roots of tomato plants (Figs. 9a and b). after treatment, total soluble proteins were isolated and analyzed by western blot using anti-PR3 antibody (upper panel). Ponceau staining was used as loading control (lower panel)

\section{Conclusions}

The synthesis of Bent-SA nanoclays resulted in a successful intercalation of the SA on the inter-laminar space of natural bentonite. The in vitro release studies of SA showed an initial fast release phase and it rests sustained for several hours. This fact was probably related to the release of SA adhered to the clay surface, and then the slow action of the water that dissolves the complex adsorbed both on the surface and in the galleries of the clay. In addition to proper physical properties, Bent-SA nano-clays combined high potential of biological functionality in plants. Thus, we propose that the effectiveness of SA was preserved in Bent nano-clays providing a useful means for its formulation and use in the horticultural field.

Acknowledgements We thank Dr. Agustin Zsögön (Universidade Federal de Viçosa, Brazil) for providing DR5:GUS Micro-Tom seeds and Dra. Danila Merino from INTEMA a

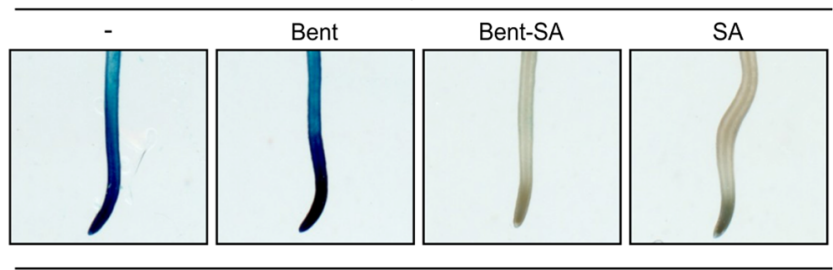

DR5:GUS

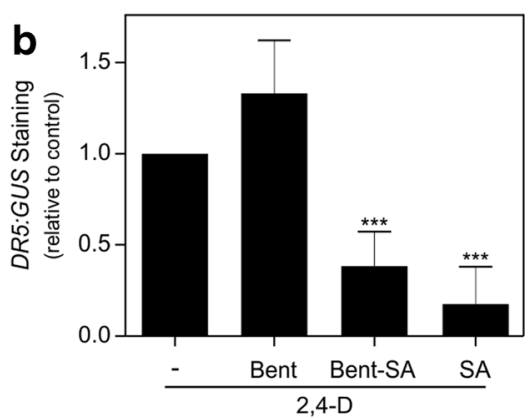

quantification of GUS staining from roots subjected to each treatment. Data are mean values $( \pm \mathrm{SD})$ of 3 independent experiments with at least 5 roots in each repeat. Statistical analysis was performed by one-way ANOVA analysis of variance. $* * * p<0.001$ (Tukey's test) 
(CONICET-UNMdP) for TEM images. This work was supported by grants from National Agency for the Promotion of Research, Technological Development and Innovation (Agencia I + D + i, PICT Start up $\mathrm{N}^{\circ} 0008$ and PICT Raíces $\mathrm{N}^{\circ}$ 0959), National Research Council (CONICET) and the National University of Mar del Plata (UNMdP) to VAA and CAC; AYM, VAA and CAC are researchers from CONICET; SLC and MFS are fellowships from CONICET.

\section{Compliance with ethical standards}

Ethics declarations Authors declared that this manuscript has not published elsewhere. All the authors have read very carefully and approved current version of this manuscript. All authors also declared that the data or images have not manipulated.

Conflict of interest The authors declare that they have no conflict of interest.

Research involving human participants and/or animals This article does not contain any studies with human participants or animals.

Informed consent All authors consent to this submission.

\section{References}

Bin Hussein, M. Z., Hashim, N., Yahaya, A. H., \& Zainal, Z. (2009). Controlled release formulation of agrochemical pesticide based on 4-(2,4-dichlorophenoxy)butyrate Nanohybrid. Journal of Nanoscience and Nanotechnology, 9, 2140-2147.

Bonina, F. P., Giannossi, M. L., Medici, L., et al. (2007). Adsorption of salicylic acid on bentonite and kaolin and release experiments. Applied Clay Science, 36, 77-85.

Cecchini, N. M., Monteoliva, M. I., \& Alvarez, M. E. (2011). Proline dehydrogenase contributes to pathogen defense in Arabidopsis. Plant Physiology, 155, 1947-1959.

Chandrasekhar, B., Umesha, S., \& Naveen Kumar, H. N. (2017). Proteomic analysis of salicylic acid enhanced disease resistance in bacterial wilt affected chilli (Capsicum annuum) crop. Physiological and Molecular Plant Pathology, 98, 85-96.

Chen, H.-J., \& Kuc, J. (1999). Ca2+-dependent excretion of salicylic acid in tobacco cell suspension culture. Botanical Bulletin of Academia Sinica, 40, 267-273.

Conlin, K. C. (2008). Effectiveness of selected chemicals in inhibiting pseudomonas syringae pv. tomato in vitro and in controlling bacterial speck. Plant Disease, 67, 639-644.

Czaban, J., \& Siebielec, G. (2013). Effects of bentonite on sandy soil chemistry in a long-term plot experiment (II); effect on $\mathrm{pH}, \mathrm{CEC}$, and macro- and micronutrients. Polish Journal of Environmental Studies, 22, 1669-1676.

D'Amico, D. A., Ollier, R. P., Alvarez, V. A., Schroeder, W. F., \& Cyras, V. P. (2014). Modification of bentonite by combination of reactions of acid-activation, silylation and ionic exchange. Applied Clay Science, 99, 254-260.

Darder, M., Colilla, M., \& Ruiz-Hitzky, E. (2003). Biopolymerclay nanocomposites based on chitosan intercalated in montmorillonite. Chemistry of Materials, 15, 3774-3780.

Davies, P. J. (2010). The plant hormones: Their nature, occurrence, and functions. In P. J. Davies (Ed.), Plant Hormones (pp 1-15). Netherlands: Springer.

Dempsey, D. A., \& Klessig, D. F. (2017). How does the multifaceted plant hormone salicylic acid combat disease in plants and are similar mechanisms utilized in humans? $B M C$ Biology, 15, 23. https://doi.org/10.1186/s12915-017-0364-8.

Durrant, W. E., \& Dong, X. (2004). Systemic acquired resistance. Annual Review of Phytopathology, 42, 185-209.

El-Nahhal, Y., Nir, S., Margulies, L., \& Rubin, B. (1999). Reduction of photodegradation and volatilization of herbicides in organo-clay formulations. Applied Clay Science, 14, $105-119$.

Elsharkawy, M. M., \& Mousa, K. M. (2015). Induction of systemic resistance against papaya ring spot virus (PRSV) and its vector Myzus persicae by Penicillium simplicissimum GP17-2 and silica (Sio2) nanopowder. International Journal of Pest Management, 61, 353-358.

Falcioni, T., Ferrio, J. P., del Cueto, A. I., Giné, J., Achón, M. Á., \& Medina, V. (2014). Effect of salicylic acid treatment on tomato plant physiology and tolerance to potato virus $\mathrm{X}$ infection. European Journal of Plant Pathology, 138, 331345.

Futalan, C. M., Kan, C.-C., Dalida, M. L., Hsien, K. J., Pascua, C., \& Wan, M. W. (2011). Comparative and competitive adsorption of copper, lead, and nickel using chitosan immobilized on bentonite. Carbohydrate Polymers, 83, 528-536.

Gkizi, D., Lehmann, S., L'Haridon, F., et al. (2016). The innate immune signaling system as a regulator of disease resistance and induced systemic resistance activity against Verticillium dahliae. Molecular Plant-Microbe Interactions, 29, 313-323.

González-Bosch, C. (2018). Priming plant resistance by activation of redox-sensitive genes. Free Radical Biology \& Medicine, 122, 171-180.

Günister, E., Pestreli, D., Ünlü, C. H., Atıcı, O., \& Güngör, N. (2007). Synthesis and characterization of chitosan-MMT biocomposite systems. Carbohydrate Polymers, 67, 358365.

Jones, J.B., Zitter, T.A., Momol, T.M., Miller, S.A. (2016) PART I: Infectious diseases. In: Jones JB, Miller SA, Momol TM, Zitter TA (eds), Compendium of Tomato Diseases and Pests, Second Edition (pp 15-119). The American Phytopathological Society.

Karlidag, H., Yildirim, E., \& Turan, M. (2009). Exogenous applications of salicylic acid affect quality and yield of strawberry grown under antifrost heated greenhouse conditions. Journal of Plant Nutrition and Soil Science, 172, 270-276.

King, E. O., Ward, M. K., \& Raney, D. E. (1954). Two simple media for the demonstration of pyocyanin and fluorescin. Translational Research, 44, 301-307.

Koo, Y. M., Heo, A. Y., \& Choi, H. W. (2020). Salicylic acid as a safe plant protector and growth regulator. The Plant Pathology Journal, 36, 1-10.

Lakraimi, M., Legrouri, A., Barroug, A., de Roy, A., \& Pierre Besse, J. (2000). Preparation of a new stable hybrid material 
by chloride-2,4-dichlorophenoxyacetate ion exchange into the zinc-aluminium-chloride layered double hydroxide. Journal of Materials Chemistry, 10, 1007-1011.

Majeed, K., Jawaid, M., Hassan, A., Abu Bakar, A., Abdul Khalil, H. P. S., Salema, A. A., \& Inuwa, I. (2013). Potential materials for food packaging from nanoclay/natural fibres filled hybrid composites. Materials \& Design, 46, 391-410.

Mansilla, A. Y., Albertengo, L., Rodríguez, M. S., Debbaudt, A., Zúñiga, A., \& Casalongué, C. A. (2013). Evidence on antimicrobial properties and mode of action of a chitosan obtained from crustacean exoskeletons on Pseudomonas syringae pv. tomato DC3000. Applied Microbiology and Biotechnology, 97, 6957-6966.

McManus, P. S., Stockwell, V. O., Sundin, G. W., \& Jones, A. L. (2002). Antibiotic use in plant agriculture. Annual Review of Phytopathology, 40, 443-465.

McNerny, D. Q., Leroueil, P. R., \& Baker, J. R. (2010). Understanding specific and nonspecific toxicities: A requirement for the development of dendrimer-based pharmaceuticals. Wiley Interdisciplinary Reviews Nanomedicine and Nanobiotechnology, 2, 249-259.

Monvisade, P., \& Siriphannon, P. (2009). Chitosan intercalated montmorillonite: Preparation, characterization and cationic dye adsorption. Applied Clay Science, 42, 427-431.

Mould, D. R., Walz, A.-C., Lave, T., Gibbs, J. P., \& Frame, B. (2015). Developing exposure/response models for anticancer drug treatment: Special considerations. CPT: Pharmacometrics \& Systems Pharmacology, 4, e00016. https://doi.org/10.1002/psp4.16.

Murashige, T., \& Skoog, F. (1962). A revised medium for rapid growth and bio assays with tobacco tissue cultures. Physiologia Plantarum, 15, 473-497.

Nayak, P. S., \& Singh, B. K. (2007). Instrumental characterization of clay by XRF, XRD and FTIR. Bulletin of Materials Science, 30, 235-238.

Olanrewaju, J., Newalkar, B. L., Mancino, C., \& Komarneni, S. (2000). Simplified synthesis of nitrate form of layered double hydroxide. Materials Letters, 45, 307-310.

Park, J.-H., Shin, H.-J., Kim, M. H., Kim, J. S., Kang, N., Lee, J. Y., Kim, K. T., Lee, J. I., \& Kim, D. D. (2016). Application of montmorillonite in bentonite as a pharmaceutical excipient in drug delivery systems. Journal of Pharmaceutical Investigation, 46, 363-375.

Pfaffl, M. W. (2001). A new mathematical model for relative quantification in real-time RT-PCR. Nucleic Acids Research, 29. https://doi.org/10.1093/nar/29.9.e45.

Rivas-San Vicente, M., \& Plasencia, J. (2011). Salicylic acid beyond defence: Its role in plant growth and development. Journal of Experimental Botany, 62, 3321-3338.

Ryals, J. A., Neuenschwander, U. H., Willits, M. G., Molina, A., Steiner, H. Y., \& Hunt, M. D. (1996). Systemic acquired resistance. Plant Cell, 8, 1809-1819.

Savjani, K. T., Gajjar, A. K., \& Savjani, J. K. (2012). Drug solubility: importance and enhancement techniques. ISRN Pharmaceutics, 2012, 195727. https://doi.org/10.5402/2012 /195727.

Shalmashi, A., \& Eliassi, A. (2008). Solubility of salicylic acid in water, ethanol, carbon tetrachloride, ethyl acetate, and xylene. Journal of Chemical \& Engineering Data, 53, 199-200.
Shenge, K. C., Wydra, K., Mabagala, R. B., \& Mortensen, C. N. (2008). Assessment of strains of Pseudomonas syringae pv. tomato from Tanzania for resistance to copper and streptomycin. Archives of Phytopathology and Plant Protection, 41, 572-585.

Silva, W. B., Vicente, M. H., Robledo, J. M., Reartes, D. S., Ferrari, R. C., Bianchetti, R., Araújo, W. L., Freschi, L., Peres, L. E. P., \& Zsögön, A. (2018). SELF-PRUNING acts synergistically with DIAGEOTROPICA to guide auxin responses and proper growth form. Plant Physiology, 176, 2904-2916.

Sudisha, J., Sharathchandra, R. G., Amruthesh, K. N., Kumar, A., \& Shetty, H. S. (2012). Pathogenesis related proteins in plant defense response. In J. M. Mérillon \& K. G. Ramawat (Eds.), Plant Defence: Biological Control (pp. 379-403). Dordrecht: Springer.

Trivedi, M., Branton, A., Trivedi, D., et al. (2015). Fourier transform infrared and ultraviolet-visible spectroscopic characterization of biofield treated salicylic acid and sparfloxacin. Natural Products Chemistry and Research, 3, 186. https://doi.org/10.4172/2329-6836.1000186.

Uppalapati, S. R., Ishiga, Y., Wangdi, T., Urbanczyk-Wochniak, E., Ishiga, T., Mysore, K. S., \& Bender, C. L. (2008). Pathogenicity of Pseudomonas syringae pv. tomato on tomato seedlings: Phenotypic and gene expression analyses of the virulence function of coronatine. Molecular PlantMicrobe Interactions, 21, 383-395.

Vallad, G. E., \& Goodman, R. M. (2004). Systemic acquired resistance and induced systemic resistance in conventional agriculture. Crop Science, 44, 1920-1934.

Vossen, J. H., Abd-El-Haliem, A., Fradin, E. F., et al. (2010). Identification of tomato phosphatidylinositol-specific phospholipase-C (PI-PLC) family members and the role of PLC4 and PLC6 in HR and disease resistance. Plant Journal, 62, 224-239.

Wang, D., Pajerowska-Mukhtar, K., Culler, A. H., \& Dong, X. (2007). Salicylic acid inhibits pathogen growth in plants through repression of the auxin signaling pathway. Current Biology, 17, 1784-1790.

Wesołowski, M. (1979). Thermal decomposition of salicylic acid and its salts. Thermochimica Acta, 31, 133-146.

Wildermuth, M. C., Dewdney, J., Wu, G., \& Ausubel, F. M. (2001). Isochorismate synthase is required to synthesize salicylic acid for plant defence. Nature, 414, 562-565.

Youssef, S. M. S., El-Azm, A., Ibrahim, N. A., et al. (2017). Frequent foliar sprayings of salicylic acid with elevated concentrations enhance growth, yield and fruit quality of strawberry (Fragaria x ananassa Duch. cv. Festival) plants. Egyptian Journal of Horticulture, 44, 61-74.

Zhang, Y., \& Li, X. (2019). Salicylic acid: Biosynthesis, perception, and contributions to plant immunity. Current Opinion in Plant Biology, 50, 29-36.

Zhang, Y., Yan, H., Wei, X., Zhang, J., Wang, H., \& Liu, D. (2017). Expression analysis and functional characterization of a pathogen-induced thaumatin-like gene in wheat conferring enhanced resistance to Puccinia triticina. Journal of Plant Interaction, 12, 332-339. 